\title{
The effect of acquisitions on firm performance: Evidence Tehran Stock Exchange
}

\author{
Farhad Hanifi $^{\mathrm{a}}$ and Shahram Vahedi ${ }^{\mathrm{b} *}$
}

${ }^{a}$ Faculty Member of Islamic Azad university, Tehran, Iran ${ }^{b}$ Ph.D. Student of Financial Management, Islamic Azad University, UAE Branch

\begin{tabular}{l}
\hline C H R O N I C L E \\
\hline Article history: \\
Received December 5, 2015 \\
Received in revised format \\
February 162016 \\
Accepted March 22016 \\
Available online \\
March 22016 \\
\hline Keywords: \\
Mergers \\
Acquisitions \\
Return on equity \\
Return on asset \\
Financial and strategic \\
acquisitions
\end{tabular}
\begin{abstract}
A B S T R A C T
Nowadays, mergers and acquisitions are stated as favorable strategies and as free flows of capital applied by managers for the optimal implementation of resources and assets. Acquisition is associated with a condition where two businesses are placed under one shelter and are run like members of a group or are merged as a single corporate. In mergers, two businesses are combined in a new form based on the mutual interests of both parties. The shares of the two businesses are usually exchanged so that they could take part in the new business as shareholders. In acquisition, a business begins to control another business effectively by purchasing parts of its ownership. The present study explored the impact of acquisition on performance of Iranian target companies listed in Tehran Stock Exchange. The results of testing research hypotheses showed that performance of target companies did not significantly increase after acquisition, suggesting a decreasing trend in the performance of the target companies after acquisition compared with the period before acquisition.
\end{abstract}

\section{Introduction}

In economics, financial and strategic management; mergers and acquisitions are regarded as favorable strategies and as free flows of capital used by managers for the optimal use of resources and assets (Hubbard, 1999). Acquisition refers to a condition where two businesses are placed under one umbrella and one control and are run like members of a group or are merged in the form of a single corporate. In mergers, two businesses are combined in a new form based on the mutual consent of both parties. The shares of the two businesses are usually exchanges so that they can partake in the new business as shareholders. In acquisition, a business starts to control another business effectively by buying parts of its ownership (Ross, 1996). Managers of buyer companies use acquisition as a tool for growth, a quick way to gain access to new markets, and as a way to enter into global trade arena, and increase profitability and efficiency. In contrast to merger and acquisition, there are another perspective based on which acquisition and merger do not have any effect or, at least, they have negative influence on the wealth of shareholders in buyer and target companies. According to opponents, growth through

* Corresponding author

E-mail address: vahedi_sh@ut.ac.ir (S. Vahedi) 
domestic development, the establishment of new projects, and newly established companies is more efficient. Based on the research conducted in this area, they claim that organizations have often experienced a severe decline in their financial performance after acquisition (Welch \& Fisher, 1992). This study aims to explore the effect of acquisition on financial criteria of firms listed in Tehran Stock Exchange.

The financial management sees the use of merger as a way to create value in buyer and target companies. Most managers at buyer companies consider acquisition as a tool to achieve growth outside the firm and as a fast method for obtaining access to new markets, entering into global trade arena, and increasing profitability and efficiency. Top managers are encouraged to use acquisition strategy for several reasons, the most important of which is to increase the shareholders' wealth, economies of scale, economies of domain, efficiency, R\&D power, corporate growth, and reduce risk. However, the main reason behind acquisition is often to increase the shareholders' wealth (Ikeda \& Doi, 1983).

Acquisition can be seen as a kind of transaction in which the buyer prohibit the reduction of market shares and does not permit new competitors enter the market. Increase in profitability and efficiency, decrease in expenses, increase (decrease) in corporate sales or growth, increase (decrease) in stock returns and operating cash flows of buyer and target firms are the main criteria for the success or failure of acquisition. Nevertheless, proponents of acquisition give counterarguments for the negative effects of acquisition on the shareholders' wealth in the buyer and target firms. Opponents of acquisition argue that growth through domestic development, the establishment of new projects, and newly established firms is more efficient. Based on the research performed in this area, companies have often experienced a severe decline in their financial performance after acquisition. Several reasons are stated for companies' decreased performance after acquisition including excessive optimism about performance, overestimating synergy, and bid war (Welch \& Fisher, 1992).

Acquisition has been increased in Iran under the influence of privatization policies and economic development programs. Managers of the buyer firms often employ acquisition a strategy to and increase shareholders' wealth.

\subsection{Acquisition turnover and trends in the world}

In 2006, the transaction record was broken and acquisition transactions reached 3500 billion dollars. During the same year, acquisition transactions accounted for $40 \%$ of transactions in Europe while this figure for the whole world was only $18 \%$ in 2000 . The corresponding figures for the U.S market in 2000 and 2006 were $36 \%$ and $46 \%$, respectively, indicating a rise in acquisition transactions. Acquisition affects shareholders' wealth in buyer and target companies and it also plays an important role at the macroeconomic level in countries. Besides, acquisition turnover and trends are of high importance for governments and corporate managers (De Langhe et al., 2001). There is rarely any company in developed countries which is not affected by acquisition waves. That is why the value of acquisition turnover in 1997 was reported over 1497 billion dollars. In addition, the turnover rate form 1996-1997 shows a 50\% rise; half of them taking place in the U.S.A. The finance industry with a turnover of over 250 billion dollars is the most active acquisition industry. Acquisition transactions reached their apex in 2000 with a transaction value of 3180 billion dollars. Following 2000, acquisition transaction experienced a sharp decline and in 2000 the acquisition turnover was equivalent to 1285 billion dollars. Acquisition strategy is used differently from one country to another so that $38.4 \%$ of the US firms and $42 \%$ of the British companies were acquisitioned over the period 1950-1970 (Dickerson et al., 1997). According to Weaver's and Weston's (2001) study, the first acquisition wave happened at the turn of the twentieth century from 1893 to 1904. In this wave, buyers used to adopt horizontal acquisition in order to create monopoly. The second acquisition started since 1916 and ended in 1926 because of the severe economic downturn. During this period, managers of the buyer companies turned to vertical acquisition which was mainly employed in the auto manufacturing industry. The sharp economic downturn followed by the World War II and antitrust regulations declined the second 
wave of acquisition and merger transactions. Form the 1940s to the 1950s, antitrust regulations and laws supporting free competition reversed the trend and acquisition and merger transactions underwent stagnancy (Weston \& Weaver, 2001).

The third acquisition wave came to the surface in the late 1970s called unrelated diversification age. The third wave was mainly characterized by risk sharing through investment diversification. Besides, the operations executed in buyer companies were not relevant to those performed in target firms and the buyers expected gaining synergy through diversifying their activities. Following the improvement of economic conditions in the 1990s, the fourth acquisition wave occurred in which the strategy of related diversification was preferred over the unrelated diversification. The use of relevant diversification strategies resulted in dissolution of insignificant and irrelevant businesses and the buyer companies focused mainly on relevant businesses. The acquisition behaviors in the 1990s were in the form of invasive acquisition.

The fifth wave started since 1993. Scholars reported the existing acquisition activities under the fifth acquisition wave which emerged in line with the globalization thinking. In other words, in the early twentieth century the corporate acquisition targetted at overcoming the national economies. At present, however, the fifth wave aims to match acquisition activities to the global scale. In the early twentieth and twenty first centuries, acquisition transactions were more evident among legal advisors, companies providing financial and banking services, and technological, IT, and automobile industries (Hubbard, 1999). Xiao and Tan (2009) explored acquisitions taken place in firms listed in the exchange stock in 2000 in China. The authors used economic value added index performances before and after the acquisition of Chinese companies. They assessed economic value added for three years before and four years after acquisition and provided their results based short-term and long-term performances. The results showed that the short-term performance of acquisitioned Chinese companies improved significantly while there was not significant improvement in terms of their long-term performance.

Yook (2004) used economic value added for the first time instead of stock returns and accounting returns to evaluate acquisition performance as the two last indices were not in line with maximizing shareholders' wealth. Besides, accounting indicators can be manipulated. The performances of buyer and target companies before and after the acquisition were evaluated using economic value added. The authors aimed to find out the potential effect of acquisition on the performance of the buyer companies through comparing the adjusted economic value added with the industry five years before and similarly five years after acquisition. They also aimed to find out changes in the performance of buyer companies in terms of transaction qualities such as type of acquisition, merger, or purchase, the quality of repayment in the form of cash or dividends, and the degree of business similarities between buyer and target companies. Determining the relationship between the premium price paid to target companies and their performances before and after acquisition was another aim of the study. The research sample included 56 merged firms and 19 acquisitioned firms listed in New York Stock Exchange and Amex from 1995 to 1989 . The payment was made in three ways: 42 cases in cash, 27 cases in dividends, and 6 cases in cash and dividends. Concerning business similarities, 52 firms were very similar and 23 firms were slightly similar. In addition, buyer firms were selected from 34 industries and target firms were selected from 30 industries. All target firms with total assets less than $\$ 100$ million were excluded from the sample.

To estimate the average economic value added, the database for performance of 100 top firms belonging to Stern Stewart Co. was used. The significance of the results and differences between the means of economic value added five years before acquisition was assessed by Wilcoxon test at the level of $0.05(\mathrm{P}=0.05)$. The results showed that the operating performance of the acquisitioning firms was reduced significantly after acquisition. While the differences in the economic value added means between the two periods before and after acquisition was high, these differences were small after estimating the industry-adjusted economic value added. A significant decrease in industry-non-adjusted economic value added resulted from the industrial effects; implying that industry with a rather low 
operating performance are more likely to be targeted by acquisition. On the other hand, if the premium price paid were included in the buyer company's assets, the economic value added after acquisition would not contribute to improving the operating performance. Therefore, the premium price paid to the target company which was excluded for the buyer company's capital in order to be able to compare their operating performances before and after acquisition without taking into account the acquisition effects. Again non-adjusted economic value added showed a decrease but adjusted economic value added showed a slight increase. It was also noted that the buyer companies showed relatively a better performance after acquisition than their counterparts in the industry. However, such performance improvement was diminished by paying high premium prices to shareholders of the target companies and this there was no real economic return for shareholders in the buyer companies. The findings generally indicted that the net value of acquisition taken by the buyer companies was equal to zero.

Mueller $(1969,1985)$ analyzed the impact of corporate acquisition in the world in the past fifteen years. They also investigated whether or not the corporate acquisition can increase the ratio of earnings before interest tax (EBIT) to assets and sales. In addition, the impact of corporate acquisition on the market power and efficiency was evaluated. The criterion for measuring efficiency and success/failure was defined as increase/decrease in earnings before interest tax (EBIT) and the sales volume (market power). The data were collected from the archived financial statements in Thompson Securities Database for the U.S.A, UK, Europe, Japan, Australia, Canada, and other countries over the period 1981-1998. The data indicated that over 69605 transactions were performed in the period under study and the total data for 44600 transactions were available in the database. The transactions were divided into three groups of horizontal, vertical, and unrelated acquisitions, each with $42 \%, 4 \%$, and $54 \%$ of cases, respectively. The average transaction value was $\$ 220$ million and the averages size of the target companies was $16 \%$ of that if the buyer companies. The most frequent acquisition was horizontal acquisition that was reported in the U.S.A. In addition, the target companies in the U.S, U.K, and Europe had a lower EBIT than the buyer companies. On the contrary, the target companies in Japan, Australia, and Canada had higher EBIT than the buyer companies. It was also noted that EBIT and efficiency increased after acquisitioning American, British, and European companies at the confidence level of $90 \%$ while the sale and market power decreased. EBIT after acquisition showed a decline for Japanese companies but their sale after acquisition improved. The findings concerning EBIT and sales for other countries were similar to the results observed for the U.S, UK, and Europe. The results also suggested that acquisition in productive companies resulted in lower EBIT compared with service companies. In addition, horizontal acquisition in productive companies (companies) brought about higher EBIT while general acquisition was more lucrative for service companies. The authors concluded that acquisition in service companies was more successful than in productive companies and horizontal acquisition had more effects on growth and sales compared with unrelated and general acquisition in both productive and service sectors. The significance of the findings of the study was assessed and reported using $t$-test (Mueller et al., 2003).

Ghosh (2001) studied the financial performance of American acquisitioned firms from 1981 to 1995. Operating cash flows and their components before and after acquisition were also evaluated. The success index was defined as increase in operating cash flows after acquisition. Operating cash flows were defined as the sale of cost of finished products sold, official and sale costs plus depreciation and goodwill costs. The sample size in this study included 315 buyer and target companies. The research variables were operating cash flows, price of products sold, and general, official, and sale costs in buyer companies. Transactions were also classified into friendly, invasive, and related acquisition. In addition 147 companies were financed in cash, 57 companies in dividends, and 111 companies were financial by a combination of cash and dividends.

The results of the study did not show any improvement in operating cash flows after acquisition. Dividend acquisition had more improvement in terms of cash flows, sale growth, and general, official, and sale costs. Human resources also showed a significant decrease in dividend acquisition and the acquisitioned companies had a better performance than the average industry's performance. The 
differences between cash and dividend acquisitions were also examined and it was found that operating cash flows of buyer companies were higher than those in the industry (Ghosh, 2001).

Rahman and Limmack (2004) assessed the financial performance of 97 buyer companies and 117 target companies from 1988 to 1992 in Malaysia. The effects of corporate acquisition in developing countries such as Malaysia were also explored. The success index was defined based on a comparison of operating cash flows two years before acquisition and the composition of financial data two years after acquisition based on data from financial statements of buyer and target companies. The authors used the model proposed by Healy et al. (1992) to assess operating cash flows in buyer and target companies, besides, they defined success index as improvement in operating cash flows of buyer and target companies. To identify and control effects of macroeconomic and industry variables, the performance of the companies under study was compared with the performance of similar companies in the industry.

Unlike Ghosh's (2001) findings, acquisition in Malaysian firms improved operating cash flows in the long term. Performance improvements after acquisition were the outcome of increase in profit margin of operating cash flows per dollar sale, asset turnover, and sale per dollar. The merged firms experienced more growth in their operating cash flows than firms in the control groups and their asset growth after acquisition was positive. It was also found that firms involved in corporate merger and acquisition had the highest growth rate. Acquisition and merger transactions in developing countries such as Malaysia improved shareholders' interests in buyer firms and macroeconomic variables of such countries. Finally, the authors assessed changes in top management of target companies after acquisition. However, they found no significant relationship in the sample under study. It was noted that target companies had higher operating cash flows than their counterparts in the industry before acquisition and operating cash flows of buyer companies were lower than operating cash flows in those active in the industry and target companies.

Dickerson et al. (1997) investigated the effects of 613 acquisition transactions on the long-term performance of British companies over a long period from 1948 to 1997. Pointing to the shortcomings of the approach to stock price movements, the authors suggested the direct assessment of corporate profitability and the use of data from financial statements (accounting research approach). To control possible effects of macroeconomic and industrial variables, the performance of 613 buyer companies was compared with that of non-acquisitioned companies. Performance evaluation index was the rate of returns on investment which is calculated as earnings before tax divided by the company's assets. Based on the findings, the authors claimed that internal investments have more positive effect on the performance of buyer companies than acquisition investments outside the organization. In addition, corporate acquisition has a negative impact on short-term and long-term profitability of buyer companies. It was also found that $47 \%$ of target companies were sold at a lower price after their profitability decreased sharply. To find out whether the results are significant or not, Kennedy and Limmack (1996) studied 247 target companies listed in the stock exchange. Based on the hypothesis that managers of buyer companies change ineffective managers to create value, the authors explored the relationship between the performance of target companies and management change. According to management change hypothesis, one of the barriers to efficiency is ineffective management that can be change to improve efficiency and create value. The relationship between stock returns and changing top executive managers in target companies was also investigated and it was found that there was no difference between target companies that changed or did not change their managers.

The change of top managers in target companies before acquisition was $6 \%$ to $10 \%$ while it reached to $40 \%$ one year after transaction and $25 \%$ two years after acquisition and with a significant increase afterwards. It was also showed that the replacement of top managers in target companies had not improved profitability at least years after acquisition. In addition, there was a negative correlation between performance before acquisitioning the target company and changing top executive managers after acquisition. To see if the results were significant or not, the student t-test was used (Kennedy \& Limmack, 1996). Healy et al. $(1992,1997)$ assessed 50 American acquisition transactions in the period 
from 1979 to 1983 using data from the main financial statements. The main issue in this study was to investigate the profitability level and value creation through corporate acquisition. The performance of buyer and target companies after acquisition was explored using operating cash flows that were estimated as sales minus the cost of sold products and the average general and official costs plus appreciation costs. To determine the success/failure of corporate acquisition and merger, the researchers did not use the stock price changes and used accounting review approach and data from financial statements. According to the researchers, accounting data were not a perfect indicator for economic performance appraisals. Therefore, they used operating cash flows to adjust financing and accounting techniques. The period under study covered five years before and after acquisition transactions. To control the effects of macroeconomic factors, the results were compared with the average operating cash flows of similar companies. The results indicated that assuming no premium price was paid by the buyer company; corporate acquisition improved the performance of the buyer company. The results of the study conducted by Healy et al. (1990) are summarized as follows:

Operating cash flows in the buyer companies compared with the industry were improved significantly as a result of a rise in productivity of buyer and target companies. In addition, operating cash flows were greater in friendly acquisitions than in invasive acquisitions. Dividend acquisitions had also a better performance than cash acquisitions. It was also found that operating cash flows were higher in related acquisitions than in unrelated acquisitions. Profit stability was also higher in strategic acquisitions than in financial acquisitions. It was also found that asset turnover ratio was significantly improved after acquisitioning target companies. Synergy was higher in strategic acquisitions and lower premium price was paid compared with financial acquisitions. There was a positive correlation between operating cash flows and increased stock values of target companies. To see if the results were significant or not, the student t-test was used (Healy et al., 1990).

\section{Methodology}

This study investigates firms listed in Tehran Stock Exchange from 2003 to 2011 which have changed management ownership and control. Due to inaccessibility of data for major transactions prior to 2003 and the lack of total access to financial statements for years before 2003, the process of extracting data started from 2003. In addition, as the study focused on at least two years before and after acquisition transactions for the purpose of data collection, the ending period of this study was 2011. Firm performance of the target companies was defined and calculated as earning income and profit. To measure corporate profit adequacy, performance ratios are used. The ratios used in this study include return on equities (ROE) and return on assets (ROA). The performance data were collected as follows:

\subsection{Return on equity}

Return on equity refers to the net income created for each dollar of equities (as resources provided by shareholders to the company). Any increase or decrease in this ratio changes shareholders' income. Since the management usually aims is to acquire the maximum return for investors in the business entity, the return on equity is one of indicators to measure the success of the business entity in reaching this goal and the users pays special attention to it when making decisions. In fact, it reflects the relationship between the firm's income and equities.

$$
R O E=\frac{\text { Earnings after tax }}{\text { Mean of ordinary equities }}
$$

\subsection{Return on assets}

Return on assets shows how much net income gains for each dollar of assets (investments). The more effective assets are uses, the more income will generate by the firm. This index shows the management efficiency in using the available resources for generating income. The higher the value of the index, the more efficient will be the firm in using its assets and resources. 


$$
R O A=\frac{\text { Net income }}{\text { Mean of assets }}
$$

These two indicators are calculated as stated Eq. (1) and Eq. (2) and their means are expressed as the performance ratio. The data related to performance were estimated by RahavardNovin Software as was stated above. Data are contained in different documents or the researcher collect and record them for the research sample. The statistics for major transactions above 5\% over 2001 to 2011 were extracted from the acquisitioned firms in Tehran Stock Exchange using RahavardNovin Software. Since acquisitions occurred in the period 2001-2011, the data for the previous years were needed, so they were collected for the period 1999-2011.

The firms under study classified major transactions higher than 5\% under block transactions and they were regarded as special symbol (major) transactions. To avoid excluding transactions traded in several $5 \%$ blocks which resulted in the management change, the data above 5\% for the target firms were collected, reviewed, and selected. In other words, the exclusion of split transactions less than 5\% were prevented using the higher than 5\% mechanism. To determine firms whose transactions resulted in changing the top and running management, the data for variables including sale, return, and performance of target firms were collected using RahavardNovin Software. It should be noted that the data for ratios of ROA and ROE were collected for the period from 1999 to 2011 . To collect the accurate data for changing major and leading management, reports from target company associations were used. Finally, the collected data were submitted to Excel and each variable was given a special worksheet.

The population under study included all Iranian target companies listed in Tehran Stock Exchange in which the management of the leading majority (with whatever percentage of stock transactions) changed and the buyer company were able to maintain or replace the majority management of the target company. Due to the small number of shareholders in Iran, the buyer company can win the majority board of director with the ownership of less than $51 \%$. It should be noted that the companies with ownership change through intragroup transactions of investment and holding companies (mother to affiliations and vice versa) were excluded for the sample. Because of the presence of different large companies and industries in Tehran Stock Exchange and the access to audited financial information and transaction data, the present study was conducted on Iranian firms listed in Tehran Stock Exchange. Due the presence of emerging public companies and industries in the Iranian capital market and the low number of companies, the research sample included all companies in the population under study. As such, 22 target companies whose majority ownership and board had changed were selected as the sample. Due to inaccessibility of data for major transactions prior to 2001 and the lack of total access to financial statements for years before 2001, the process of extracting data started from 2001. In addition, the data from basic financial statements were collected for the period at least two years before and after transactions taking place in the sample firms. The following hypotheses were tested in this study:

- There is a significant difference in performance of target companies before and after acquisition.

- There is a significant difference in return on equities of target companies before and after acquisition.

- There is a significant difference in return on assets of target companies before and after acquisition.

Accordingly, the following research questions were addressed in this study:

- Is there any significant difference in performance of target companies before and after acquisition? 


\section{The results}

\subsection{The main hypothesis}

The pairwise t-test was used to test the research hypothesis, stated as follows:

$\mathrm{H}_{0}$ : There is no significant difference in performance of target companies before and after acquisition.

$\mathrm{H}_{1}$ : There is a significant difference in performance of target companies before and after acquisition.

Table 1 and Table 2 show the results of testing the hypothesis using t-student and ANOVA tests.

\section{Table 1}

The results of testing the hypothesis using t-test and F-test

\begin{tabular}{lccc}
\hline Method & df & Value & Prob. \\
\hline t-test & 42 & 0.025505 & 0.9798 \\
F-test & $(1,42)$ & 0.000650 & 0.9798 \\
\hline
\end{tabular}

\section{Table 2}

The results of ANOVA test

\begin{tabular}{lccc}
\hline Source of variations & df & Sum of Squares & Mean of squares \\
\hline Between & 1 & 0.204545 & 0.204545 \\
Within & 42 & 13206.95 & 314.4513 \\
\hline Total & 43 & 13207.16 & 307.1432 \\
\hline
\end{tabular}

As shown in Table 1 and Table 2, the significance level for the hypothesis is not significant (0.9798) and the null hypothesis is confirmed. Consequently, it can be suggested that there is no significant difference in rate of performance of target companies before and after acquisition at $95 \%$ confidence level and the hypothesis is rejected. In other words, acquisition did not lead to an increase in performance of the target companies after acquisition and the acquisitioning companies were not able to improve the acquisitioned companies in terms of profitability.

\subsubsection{Results of testing ROE hypothesis}

The first sub-hypothesis stated there is no significant difference in return on equities of target companies before and after acquisition. The pairwise t-test was used to test the first sub-hypothesis which is stated as follows:

$\mathrm{H}_{0}$ : There is no significant difference in return on equities of target companies before and after acquisition.

$\mathrm{H}_{1}$ : There is a significant difference in return on equities of target companies before and after acquisition.

Table 3 and Table 4 show the results of testing the hypothesis using t-student and ANOVA tests.

Table 3

The results of testing the hypothesis using t-test and F-test for the first sub-hypothesis

\begin{tabular}{lccc}
\hline Method & df & Value & Prob. \\
\hline t-test & 42 & 0.570878 & 0.5711 \\
F-test & $(1,42)$ & 0.325902 & 0.5711 \\
\hline
\end{tabular}

\section{Table 4}

The results of ANOVA test for the first sub-hypothesis

\begin{tabular}{lccc}
\hline Source of variations & df & Sum of Squares & Mean of squares \\
\hline Between & 1 & 349.4545 & 349.455 \\
Within & 42 & 45035.27 & 1072.268 \\
\hline Total & 43 & 45384.73 & 1055.459 \\
\hline
\end{tabular}


As it is shown in Table 3 and Table 4, the significance level for the first sub-hypothesis is not significant (0.5711) and thus it can be suggested that there is no significant difference in return on equities (ROE) of target companies before and after acquisition at $95 \%$ confidence level and the first sub- hypothesis is rejected. In other words, acquisition did not lead to an increase in ROE in the target companies after acquisition.

\subsubsection{Results of testing ROA hypothesis}

The second sub- hypothesis stated that there is no significant difference in return on assetsin target companies before and after acquisition. The pairwise t-test was used to test the first sub- hypothesis which is stated as follows:

$\mathrm{H}_{0}$ : There is no significant difference in return on assets in target companies before and after acquisition.

$\mathrm{H}_{1}$ : There is a significant difference in return on assets in target companies before and after acquisition.

Table 5 and Table 6 show the results of testing the hypothesis using t-student and ANOVA tests.

\section{Table 5}

The results of testing the hypothesis using t-test and F-test for the second sub-hypothesis

\begin{tabular}{lccc}
\hline Method & $\mathrm{df}$ & Value & Prob. \\
\hline t-test & 42 & 0.321503 & 0.7494 \\
F-test & $(1,42)$ & 0.103364 & 0.7494 \\
\hline
\end{tabular}

\section{Table 6}

The results of ANOVA test for the second sub-hypothesis

\begin{tabular}{lccc}
\hline Source of variations & df & Sum of Squares & Mean of squares \\
\hline Between & 1 & 11.000 & 11.000 \\
Within & 42 & 4469.636 & 106.4199 \\
\hline Total & 43 & 4480.636 & 104.2008 \\
\hline
\end{tabular}

As it can be seen from the results of Table 5 and Table 6, the significance level for the second subhypothesis is not significant $(0.7494)$ and thus it can be suggested that there is no significant difference in return on assets (ROA) among target companies before and after acquisition at $95 \%$ confidence level and as a result the null hypothesis is confirmed. This shows that acquisition did not lead to an increase in ROA in the target companies after acquisition.

\section{Conclusion}

In this paper, we have investigated the effects of merger on firm performance for selected firms listed on Tehran Stock Exchange. The study has used the information of over ten year-period and using ROA and ROE as an indicators for firm performance, it has determined that major had no effect on firm performance on this exchange. In other words, the results have indicated that performance of target companies did not significantly increase after acquisition, suggesting a decreasing trend in the performance of the target companies after acquisition compared with the period before acquisition. The results of this survey are somewhat consistent with findings of Ravenscraft and Scherer (1987), Frankel (2005), Clark and Ofek (1994), Ghemawat and Ghadar (2000), Smith (2000) and Strickland (1998).

\section{References}

Clark, K., \& Ofek, E. (1994). Mergers as a means of restructuring distressed firms: An empirical investigation. Journal of Financial and Quantitative Analysis, 29(04), 541-565.

Chamberlain, K. (2015). Valuation local authorities. www.theauthority.com 
De Langhe, T., Ooghe, H., \& Camerlynck, J. (2001). Are Acquisitions Worthwhile? An Empirical Study of the Post Acquisition Performance of Privately Held Belgian Companies Involved in Takeovers. An Empirical Study of the Post Acquisition Performance of Privately Held Belgian Companies Involved in Take-overs (December 2001). EFMA.

Dickerson, A. P., Gibson, H. D., \& Tsakalotos, E. (1997). The impact of acquisitions on company performance: Evidence from a large panel of UK firms. Oxford Economic Papers, 49(3), 344-361.

Economic value added: Advantages of EVA (2015). www.stwenstewart.com.

Frankel, M. (2005). Mergers and acquisitions Basics. John Wiley \& Sons, Inc.

Ghemawat, P., \& Ghadar, F. (2000). The dubious logic of global megamergers. Harvard Business Review, 78(4), 64-74.

Ghosh, A. (2001). Does operating performance really improve following corporate acquisitions?. Journal of corporate finance, 7(2), 151-178.

Gugler, K., Mueller, D. C., Yurtoglu, B. B., \& Zulehner, C. (2003). The effects of mergers: an international comparison. International journal of industrial organization, 21(5), 625-653.

Healy, P. M., Palepu, K. G., \& Ruback, R. S. (1997). Which takeovers are profitable? Strategic or financial. MIT Sloan Management Review, 38(4), 45.

Healy, P. M., Palepu, K. G., \& Ruback, R. S. (1992). Does corporate performance improve after mergers?. Journal of financial economics, 31(2), 135-175.

Hubbard, N. (1999). Acquisition strategy and implementation. Purdue University Press.

Ikeda, K., \& Doi, N. (1983). The performances of merging firms in Japanese manufacturing industry: 1964-75. The Journal of Industrial Economics, 16(3), 257-266.

Kennedy, V. A., \& Limmack, R. J. (1996). Takeover activity, CEO turnover, and the market for corporate control. Journal of Business Finance \& Accounting, 23(2), 267-285.

Mueller, D. C. (1969). A theory of conglomerate mergers. The Quarterly Journal of Economics, 83(4), 643-659.

Mueller, D. C. (1985). Mergers and market share. The Review of Economics and statistics, 67(2), 259267.

Rahman, R. A., \& Limmack, R. J. (2004). Corporate acquisitions and the operating performance of Malaysian companies. Journal of Business Finance \& Accounting, 31(3-4), 359-400.

Ravenscraft, D. J., \& Scherer, F. M. (1987). Life after takeover. The Journal of Industrial Economics, 36(2), 147-156.

Ross, S. A., Westerfield, R. W., \& Jaffe, J. F. (1996). Corporate Finance: Irwin. Homewood, IL, 60430.

Rezaee, Z. (2004). Financial institutions, valuations, mergers, and acquisitions: the fair value approach. John Wiley \& Sons.

Seth, A. (1990). Value creation in acquisitions: A re-examination of performance issues. Strategic Management Journal, 11(2), 99-115.

Shusta, A. (1999). Are you paying too much for that acquisition?. Harvard Business Review, 77(6), 190-190

Singh, H., \& Montgomery, C. A. (1987). Corporate acquisition strategies and economic performance. Strategic Management Journal, 8(4), 377-386.

Smith, K. W. (2000). A brand-new culture for the merged firm. Mergers and Acquisitions, 35(6), 4550.

Strickland, A. J. (1998). Strategic management: concepts and cases. Richard d Irwin.

Welch, H. G., \& Fisher, E. S. (1992). Let's make a deal: negotiating a settlement between physicians and society. New England Journal of Medicine, 327(18), 1312-1315.

Weston, J., \& Weaver, S. (2001). Mergers and acquisitions. The McGraw-Hill Executive MBA Series, McGraw-Hill.

Xiao, X., \& Tan, L. (2009, June). Research of M\&A Performance of Listed Companies in China Based on EVA. In Electronic Commerce and Business Intelligence, 2009. ECBI 2009. International Conference on (pp. 337-340). IEEE.

Yook, K. C. (2004). The measurement of post-acquisition performance using EVA. Quarterly Journal of Business and Economics, 43(3/4), 67-83. 